\section{Advancement of a Common Wheat (Triticum aestivum L.) Selection System}

\author{
Szilárd Tóth - Henriett Kovács Oskolás \\ University of Debrecen, Centre for Agricultural Sciences, \\ Faculty of Agricultural Sciences, \\ Department of Genetics and Plant Breeding, Debrecen \\ tszi@agr.unideb.hu
}

\section{SUMMARY}

All the research in Hungary and other countries in Europe focus on improving the quality of crops and increasing the competitiveness of production.

In this respect, we have to advance the conventional technological elements, reduce the application of pesticides and fertilizers, and produce new varieties suitable for environmentallysound production. In our crop breeding programs, we applied conventional and biotechnological methods (embryo rescue and double haploid methods) in order to get somaclonal and gametoclonal variations.

We produced winter wheat lines (HP-31-95, HP-82-96) by traditional way, which have high baking qualities and high nutrient efficiency. Some diseases can limit the quantity and quality of a wheat crop. We examined several wheat diseases in our winter wheat candidates, and we found that our progenies have resistance to leaf rust.

With respect to a serious problem was the small quantity of applied fertilizers and the other externals, our research focused onto advance a common wheat selection system, with the help of it, we can handle these problems. We have summarized that our selected progenies can compete with the registered varieties with quality and environmental respect.

Keywords: winter wheat, baking qualities, disease

\section{INTRODUCTION}

A large selection of winter wheat varieties (more than 100) is grown in Hungary. These are very different not only in their genetic background but in their reaction to the environment and agrotechnology. This is why, we have to investigate their reacts to ecological conditions (Konzak and Pepo, 1991). A possible future for cereal breeding is the selection of adaptable varieties under Hungarian agro-ecosystems (Pepo et al., 2004).

In the breeding programs, we must use the physiological parameters of the wheat varieties, such as nitrate reductase activity (Manolov et al., 1999). There are large differences among the resistance of different genotypes (Mesterházy, 1999; Csontos et al., 1993). Resistance of winter wheat varieties produced in Hungary to mildew/rust is not sufficient excepting a few genotypes, which is why there was a broad investigation of wheat lines tolerance/resistance using diallel analysis (Pepó Pál, 1995). Several new techniques are used in order to breed varieties with better characteristics, and stable performance in quantity and quality (Pepo et al., 2005). Our challenge in sustainable winter wheat production is to decrease the susceptibility of varieties to diseases and to increase their resistance (Rozalski et al., 1998; Jorgensen et al., 1999).

Pepo Pal (2004) identified a new group of genotypes suitable for environmentally-friendly farming based on fertilizer response of different winter wheat varieties. The common features of those varieties were high efficient nutrient utilization, low nutrient demands and excellent baking quality. The growing concern about the negative impact of present-day agricultural practices on the environment is a driving force behind the development of varieties which are friendly to the environment and provide many of the answers to the problems of today and tomorrow (Pepo Pal, 1998).

The anther and embryo culture was successfully applied in wheat/triticale breeding programme by Tuvesson et al., 2000). The method used to improve the efficiency of conventional breeding in wheat was described by Pepó Pál, 2005a, 2005b). The technique was continuously developed by (Karsai et al., 1992; Zamani et al., 2000; Pauk et al., 1995; Rubio et al., 2004).

Genetic manipulation may not replace any conventional method in crop breeding programs, but it can be an important adjunct to them. The production of haploid plants from wheat anther culture has become a practice included in many plant breeding programs because of progress in anther culture methodology (Pepo Pal, 1997).

\section{MATERIALS AND METHODS}

We conducted our research in the Experimental Field of Debrecen University, which is suitable for winter wheat production.

We started our breeding work with crosspollination using the best Hungarian, European and American varieties/lines/landraces. Cross combinations were built up with application of different types of crosses and number of parent lines.

Gluten content was determinated according to MSZ ISO 5531 standard by Glutomatic Perten instrument, while valiograph value was measured according to MSZ ISO 5530-3 standard by Valiograph FQA instrument, than by Farinograph. We did not use nitrogen fertilizer in one part of our field to select varieties with high nutrient efficiency. In our latitude $\left(47^{\circ}\right)$, we tested winter hardiness as well. Our disease problems are mainly powdery mildew (Blumeria graminis f. sp. tritici) and leaf rust (Puccinia recondite f. sp. tritici), as well as stem rust and different bunts. 
We applied biotechnology - mainly double haploid techniques - in order to get genetically homogenous lines which are suitable for sustainable production in a short period. In our breeding programme we used embryo culture which was described by Karsai in 1992 and we applied haploid technique that was developed by Pauk in 1995.

\section{RESULTS}

We estimated quite a large number of different parameters in our winter wheat breeding programme. We put the main point on the progeny originated from such a wheat varieties which can give high yield without application of fertilizers. We selected descendants from the $\mathrm{F}_{2}$ generation (Figure 1).

Figure 1: Application of conventional methods of common wheat selection system

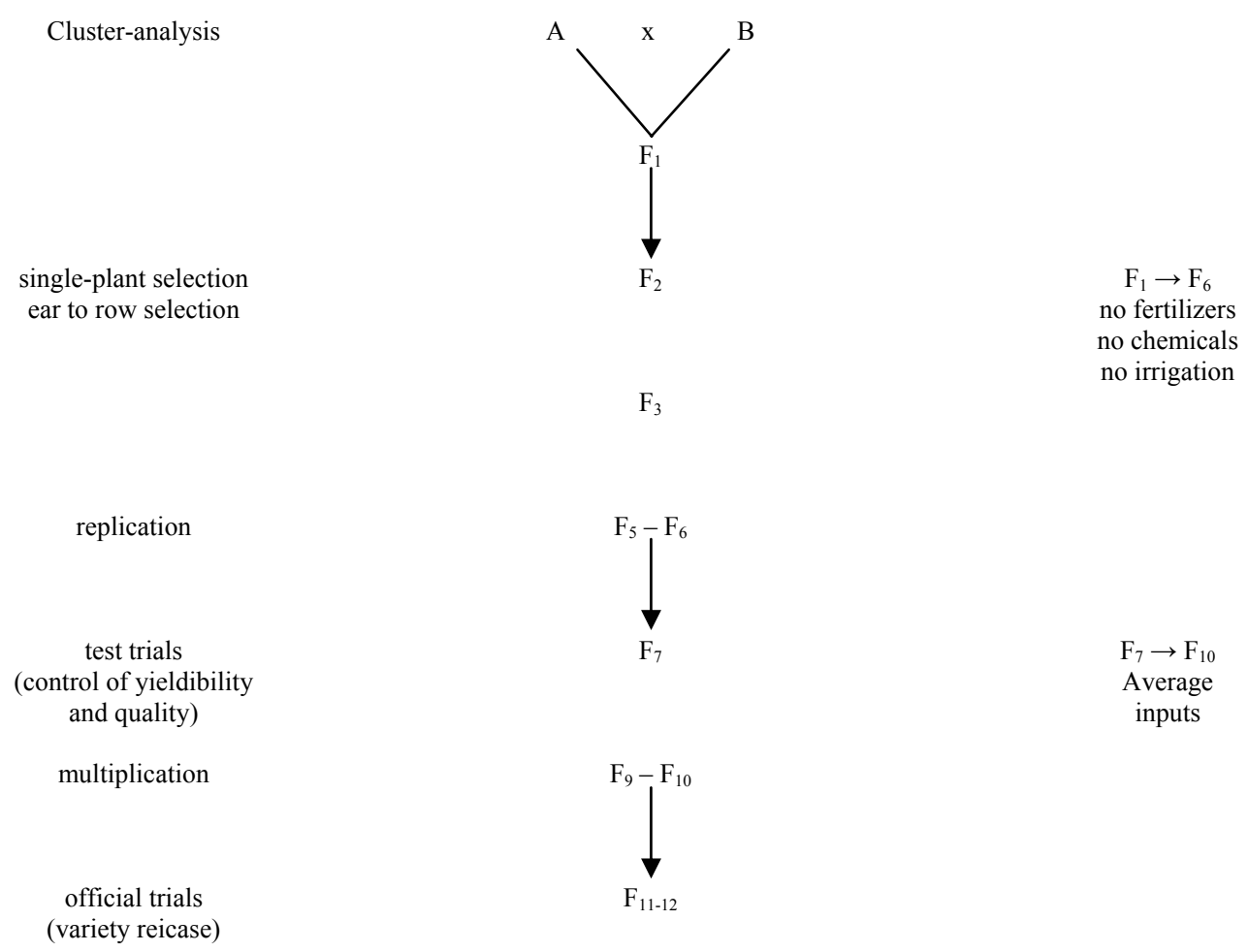

We estimated the quality and resistance in our winter wheat breeding programme. The strict selection was built on the ear-to-row procedure and the crossed generations were tested in microreplications. We took the intermediers which have favorable characteristics for organic agriculture in a recombinant form. Investigations were extended to the parameters which are changeable, as a consequence of oligo- and monogene determination.
We selected ear lines because the cross-combinations were not necessary homozigote. We investigated the wet gluten content, the Hagberg-falling number and the baking quality. The ear lines can allow for the making of divergent selection, which may produce more and more valuable lines.

We used biotechnological approaches for advancement of our cereal breeding program (Figure 2).

Figure 2: Advancement of cereal breeding through biotechnological approaches

Hybridization
$\begin{gathered}\text { Immature embryo culture } \\ \text { (somaclonal variation) } \\ \begin{array}{c}\text { Double haploid technology } \\ \text { (gametoclonal variation) }\end{array}\end{gathered}$
(sodium-azide)


We can use mutation breeding before we apply different genotypes for hybridization. We have possibilities for somaclonal and gametoclonal variation using immature embryo culture and double haploid technology. We found the $\mathrm{DH}$ technology as an efficient method for the recombination of desired trait into a genotype, new combination for resistance and screening under artificial conditions.

In Table 1, we can see that the selected progenies compete with the registed varieties with yieldability, thousand kernel mass, stability and winter hardiness. Own varieties (HP-31-95, HP-82-96) was created by conventional crosses. We can say the same in the quality features, such as gluten content and the baking quality.

As regards the pathological data (Table 2), our winter wheat candidate has resistance to leaf rust.

Results of the comparative small-plot variety experiments, Middle-ripening group „A” experiment

\begin{tabular}{|c|c|c|c|c|c|c|}
\hline Varieties & $\begin{array}{c}\text { Grain } \\
\text { (t/ha) } \\
\text { (rel. \%) }\end{array}$ & $\begin{array}{l}\text { Thousand kernel } \\
\text { mass } \\
\text { (g) }\end{array}$ & $\begin{array}{c}\text { HI-mass } \\
\text { (kg) }\end{array}$ & $\begin{array}{l}\text { Plant height } \\
\text { (cm) }\end{array}$ & $\begin{array}{c}\text { Stability } \\
(1-10)\end{array}$ & $\begin{array}{l}\text { Winter- } \\
\text { hardiness } \\
(1-10)\end{array}$ \\
\hline St. GK Öthalom & $\begin{array}{r}7.41 \\
105.40\end{array}$ & 44.0 & 74.7 & 88 & 3.31 & 8.5 \\
\hline St. GK Góbé & $\begin{array}{r}6.88 \\
97.90 \\
\end{array}$ & 37.2 & 77.8 & 84 & 5.50 & 8.3 \\
\hline St. Mv 19 & $\begin{array}{r}6.79 \\
96.60 \\
\end{array}$ & 49.9 & 77.3 & 95 & 4.16 & 8.7 \\
\hline HP $31-95$ fj. (2) & $\begin{array}{r}7.17 \\
102.00\end{array}$ & 48.9 & 77.9 & 91 & 3.61 & 8.9 \\
\hline
\end{tabular}

10 is the best

Pathological data of middle winter wheat varieties (infected surface \%)

\begin{tabular}{|c|r|r|r|r|r|}
\hline \multirow{2}{*}{ Varieties } & \multicolumn{2}{|c|}{ Mildew } & \multicolumn{1}{c|}{ Stem rust } & \multicolumn{2}{c|}{ Leaf rust } \\
\cline { 2 - 6 } & \multicolumn{1}{|c|}{$\begin{array}{c}\text { Variety } \\
\text { experiment }\end{array}$} & \multicolumn{1}{c|}{$\begin{array}{c}\text { Provocation } \\
\text { experiment }\end{array}$} & $\begin{array}{c}\text { Provocation } \\
\text { experiment }\end{array}$ & \multicolumn{2}{c|}{ Variety experiment } \\
\hline GK Öthalom & 11.3 & 27.5 & 75.0 & - & - \\
\hline Mv 19 & 19.6 & 20.0 & 7.5 & -5 & -5 \\
\hline GK Góbé & 11.0 & 20.0 & 17.5 & - & - \\
\hline HP 31-95 & 18.3 & 22.5 & 30.0 & 1.9 & 3.7 \\
\hline Average & 17.6 & 24.8 & & & - \\
\hline
\end{tabular}

- no infection at all

At the present time, in the selection of new wheat lines, the quality features and the environmental respects are more important than the conventional, yield-oriented technological points of view. We have such a sortiment with perspective lines which have a stable A2 flour quality, high nutrient efficiency resistance to biological and abiological stresses and drought resistance. They have high gluten content, and their Hagberg-number is continuously stable (Table 3, 4).

Results of the comparative small-plot variety experiments, Late varieties

\begin{tabular}{|c|c|c|c|c|c|c|}
\hline Varieties & $\begin{array}{c}\text { Grain } \\
\text { (t/ha) } \\
\text { (rel. \%) }\end{array}$ & $\begin{array}{l}\text { Thousand kernel } \\
\text { mass } \\
\text { (g) }\end{array}$ & $\begin{array}{c}\text { HI-mass } \\
\text { (kg) }\end{array}$ & $\begin{array}{l}\text { Plant height } \\
\text { (cm) }\end{array}$ & $\begin{array}{c}\text { Stability } \\
(1-10)\end{array}$ & $\begin{array}{c}\text { Winter- } \\
\text { hardiness } \\
(1-10)\end{array}$ \\
\hline St. GK Öthalom & 6.99 & \multirow{2}{*}{43.9} & \multirow{2}{*}{75.3} & \multirow{2}{*}{101} & \multirow{2}{*}{4.41} & \multirow{2}{*}{8.0} \\
\hline & 0.00 & & & & & \\
\hline St. GK Góbé & 6.98 & \multirow{2}{*}{44.3} & \multirow{2}{*}{72.2} & \multirow{2}{*}{95} & \multirow{2}{*}{4.71} & \multirow{2}{*}{7.5} \\
\hline & 99.90 & & & & & \\
\hline St. Mv 19 & 9.48 & \multirow{2}{*}{38.6} & \multirow{2}{*}{75.9} & \multirow{2}{*}{95} & \multirow{2}{*}{4.13} & \multirow{2}{*}{8.4} \\
\hline & 92.70 & & & & & \\
\hline HP 31-95 fj. (2) & 6.67 & 38.8 & 76.0 & 103 & 4.34 & 8.4 \\
\hline
\end{tabular}

10 is the best 
Baking qualities of late winter wheat varieties

\begin{tabular}{|c|c|c|c|c|}
\hline Varieties & $\begin{array}{c}\text { Gluten content } \\
(\%)\end{array}$ & $\begin{array}{l}\text { Gluten extending } \\
\text { (mm) }\end{array}$ & Baking quality values & Baking quality group \\
\hline Theese & 26.5 & 3.3 & 53.9 & B-2 \\
\hline Mv Matador & 26.5 & 1.5 & 51.9 & B-2 \\
\hline Mv Magdalena & 36.7 & 4.6 & 56.5 & B-1 \\
\hline HP 82-96 & 31.5 & 1.6 & 71.1 & A-2 \\
\hline
\end{tabular}

We have lines in the early-, mid - late and late ripening groups. These lines have been published earlier (Pepo Pal, 2004). Their productivity, quality, adaptability, the effectiveness and the suitability for sustainable production fulfill these new requirements.

In many European countries, such as Hungary, we are pushed to improve the quality of final products and protect our environment and make our economic system more efficient in agriculture. This was the reason for the advancement of a common wheat selection system.

\section{REFERENCES}

Csontos, Gy.-Nemeskéri, E.-Pepó, Pál-Pepó, P. (1993): Correlation between the biological, ecological, production factors, and the quality. int. Conf. 125 Anniversary, DATE, 239-242.

Jorgensen, L. N.-Rasmussen, G.-Olseen, C. C.-Olsen, J. E.-Jensen, L. S. (1999): Effect of nitrogen on development of diseases and on weeds in winter wheat. Gron-Viden, Markburg, 8. 213.

Karsai, I.-Bedö, Z.-Balla, L. (1992): Intravarietal variability in anther culture of wheat (Triticum aestivum L.). Plant Production, 41. 2. 105-112.

Konzak, C.-Pepo, Pal (1991): Advancement of cereal production and breeding through collaboration between USA and Hungary. Crop and Soil Sciences Report, WSU, 56.

Manolov, I.-Chalova, V.-Kostadinova, S. (1999): Effect of nitrogen fertilization and variety differences on nitrate reductase activity of wheat (Triticum aestivum). Bulgarian Journal of Agricultural Sciences, 4. 599-604.

Mesterházy, Á. (1999): Fajtaspecifikus védekezés a búza kalászfuzárium ellen. Gyakorlati Agrofórum, 10. 5. 13-16.

Pauk, J.-Kertész, Z.-Berke, B.-Bóna, L.-Csősz, M.-Matúz, J. (1995): New winter wheat variety GK Delibab developed via combining conventional breeding and in vitro androgenesis. Cereal research Communications, 23. 3. 251-256.

Pepó, Pál (1995): Winter wheat (Triticum aestivum) production in the Hungarian sustainable agriculture. Int. Conference on Sustainable Agriculture, Hisar, India, Abstracts, 110-111.

Pepo, Pal (1997): Genetic manipulation in agricultural environment. Columbia University, 1995-1997. XXX. 103122.

Pepo, Pal (1998): Wheat and maize improvement for sustainable agriculture. Sustainable Agriculture for Food, Energy and Industry, James \& James (Science Publishers) Ltd., 655-657.

Pepo, Pal (2004): Fertilizer response of new winter wheat
(Triticum aestivum L.) genotypes. Plant Production, 53. 5. 429-524.

Pepó, Pál (2005a): Imporovment of double haploid (DH) production in wheat (Triticum aestivum L.). Plant Production, 54. 1. 1-10.

Pepo, Pal (2005b): Dialel analysis of resistance of powdery mildew (Blumeria graminis f.sp. tritici) and leaf rust (Puccinia recondite f.sp.tritici) in winter wheat (Triticum aestivum L.) genotypes. Növénytermelés, 54. 4. 243-252.

Pepo, Pal-Toth, Sz.-Oskolas, H.-Bodi, Z.-Erdei, E. (2005): Quality investigation of winter wheat (Triticum aestivum L.) lines in different years. Növénytermelés, 54. 3. 137-143. HU ISSN 0546-8191

Pepo, Pal-Toth, Sz.-Sipos, L. (2004): Development of new winter wheat (Triticum aestivum L.) varieties under Hungarian agroecosystems. III. Alps-Adria Scientific Workshop, 358-362.

Rozalski, K.-Pudelko, J.-Skrzypczak, G. (1998): Disease incidence in winter wheat and spring triticale as influenced by crop protection and nitrogen. Progress in Plant Protection, Akademia Rolnicza, Poznan, 38. 2. 551-554.

Rubio, S.-Jouve, N.-Gonzales, J. M. (2004): Biolistic transfer of the gene uidA and its expression in haploid embry-like structures of triticale (xTriticosecale Wittmarc). Plant cell Tissue and Organ Culture, 77. 2. 203-209.

Tuvesson, S.-Ljunberg, A.-Johansson, N.-Karlsson, K. E.-Suijs, L. W.-Josset, J. P. (2000): Large-scale production of wheat and triticale double haploids through the use of a single-anther culture method. Plant Breeding, 119. 6. 455-459.

Zamani, I.-Kovács, G.-Gouli-Vavdinouudi, E.-Roupakins, D. G.Barnabas, B. (2000): regeneration of fertile double haploid plants from colhicine-supplemented media in wheat anther culture. Plant breeding, 119. 6. 461-465. 